\title{
The value of supplementary feeding to pre-weaned and weaned lambs grazing Italian ryegrass
}

\author{
J.F. de Villiers", T.J. Dugmore and J. J. Wandrag \\ KwaZulu-Natal Department of Agriculture and Environmental Affairs, \\ Private Bag X9059, Pietermaritzburg 3200, South Africa
}

\begin{abstract}
The variation in, and often the disappointingly poor weight gains and the inability of lambs to achieve desirable carcass grades on ryegrass pastures have long been a concern to researchers, extension officers, advisors and farmers. The objectives of this study were to investigate whether concentrate supplementation to lambs on Italian ryegrass (Lolium multiflorum cv Midmar) pastures would improve the performance of lambs, and what the optimum level of supplementation is to lambs on the pasture. The investigation extended over the pre- and post-weaning growth phases of lambs and was conducted during two consecutive seasons at the Cedara Research Station in the KwaZulu-Natal Mistbelt. The pre-weaning stocking rate applied, was 20 South African Mutton Merino ewes with lambs/ha and the following treatments were applied: Control: continuous grazing - no creep feed; forward creep grazing by the lambs in a rotational grazing system where the lambs were allowed to graze paddocks allocated to the ewes, plus the next paddock in their series of grazing paddocks; $100 \mathrm{~g}$ creep feed/lamb/day; $250 \mathrm{~g}$ creep feed/lamb/day and creep feed $a d$ libitum. The post-weaning stocking rate applied, was $50 \mathrm{lambs} / \mathrm{ha}$ and treatments were: Control - no supplement; $250 \mathrm{~g}$ of supplement/lamb/day (only the second season); $500 \mathrm{~g}$ of supplement/lamb/day and supplement ad libitum. From 42 days of age to weaning, supplementation significantly improved the live weight gain of suckling lambs. Creep feed intake varied between 300 and $350 \mathrm{~g} / \mathrm{lamb} /$ day. The average daily gain of the weaned lambs improved significantly with supplementation. No significant advantage in terms of growth was gained by supplementing the weaned lambs at levels of higher than $500 \mathrm{~g} /$ day.
\end{abstract}

Keywords: lambs, creep feed, intake, performance, supplement, annual ryegrass

"Corresponding author. E-mail: devilliersj@dae.kzntl.gov.za

\section{Introduction}

The poor performance of lambs on annual Italian ryegrass (Lolium multiflorum cv Midmar) pastures, considering its nutritive value of $c .200 \mathrm{~g}$ crude protein (CP)/kg dry matter (DM) and $10 \mathrm{MJ}$ metabolisable energy (ME)/kg DM (Dugmore, 1995), is a general complaint among sheep farmers in KwaZulu-Natal. This is supported by studies in the KwaZulu-Natal Midlands where poor average daily gains (ADG) of $92 \pm 6.67$ $\mathrm{g}$ /day have been recorded in lambs on ryegrass during the last month before weaning, compared to gains of $208 \pm 8.38 \mathrm{~g}$ /day for the first 42 days of lactation (de Villiers et al., 1993). It was suggested that the ewe's milk can sustain a high ADG during early lactation, but that the rapid decline in milk yield after six weeks of lactation deprives the lamb grazing fresh grass of rumen undegradable protein (UDP) (Robinson, 1990). Thomson et al. (1982) regarded the low concentration of UDP in fresh grass as a major limitation in its nutritional value, which would restrict the performance of grazing ruminants, particularly growing and lactating ruminants. However, Joyce \& Rattray (1970) considered the two main factors limiting the growth of unweaned lambs reared on cultivated pastures to be the inability of a lamb's rumen to utilise pasture and its relatively small rumen size when consuming such a high moisture diet.

A standard practice in the KwaZulu-Natal Midlands is to grow out lambs after weaning on ryegrass pastures, aiming at a target slaughter weight of $c .45 \mathrm{~kg}$. Smith et al. (1986) using a "put and take" grazing procedure, achieved weight gains of between 150 and $200 \mathrm{~g} /$ day in weaned Döhne Merino lambs on irrigated Italian ryegrass, while Jaqusch et al. (1979) recorded ADG's of between 47 and $183 \mathrm{~g}$ /day in lambs on a ryegrass/clover pasture. De Villiers et al. (1995) reported a weight gain of $169 \pm 4.99 \mathrm{~g} / \mathrm{day}$ in weaned lambs when the pre-weaning stocking rate was 20 ewes with lambs/ha and $147 \pm 5.26 \mathrm{~g} /$ day at a pre-weaning stocking rate of 36 ewes with lambs/ha.

Johnson \& Light (1965) showed that lambs receiving a creep feed from four weeks of age, were on average $6.3 \mathrm{~kg}$ heavier at weaning than lambs on pasture only. Likewise, Light \& Haugse (1965) reported that lambs receiving a creep feed were marketable 28 days earlier than lambs without the creep feed. The lamb's ability to increase herbage intake is affected by the degree of competition for herbage with the ewe 
(Gibb \& Treacher, 1978). Therefore, supplementation should reduce such competition between lamb and ewe. The problem of competition for grass between ewe and lamb would be exacerbated by the relatively high instantaneous grazing pressure due to the high concentration of animals under rotational grazing systems (Warner \& Sharrow, 1984). On the other hand, an advantage of supplementation is that a pasture can be grazed down to a point suitable for proper pasture management without the risk of poor animal performance (Van Ryssen et al., 1976).

The wide variation in weight gains, the often disappointingly poor growth and consequently the inability of lambs to achieve desirable carcass grades on ryegrass pastures have been a concern to researchers, extension officers, advisors and farmers in the region. The objectives of this study were to establish whether the supplementation of concentrates to lambs on Italian ryegrass pastures could improve the performance of the lambs, and to determine the optimum intake of the concentrate supplement from a biological point of view.

\section{Materials and Methods}

The investigation covered the pre- and post-weaning growth phases of lambs and was conducted during two consecutive winter seasons at the Cedara Research Station in the KwaZulu-Natal Mistbelt. The altitude at Cedara is $1075 \mathrm{~m}$ with an average annual rainfall of $885 \pm 142 \mathrm{~mm}$, predominantly during summer (October to March). Italian ryegrass (cv. Midmar) was established annually during February on a 3.5 ha bottomland (Katspruit soil form) at a seeding rate of $25 \mathrm{~kg} / \mathrm{ha}$ and fertilized at the recommended level of $350 \mathrm{~kg}$ nitrogen $(\mathrm{N}) / \mathrm{ha} /$ season. The trial was conducted during the dry winter months and the pasture was irrigated weekly at an application rate of approximately $25 \mathrm{~mm}$.

During the pre-weaning stage a stocking rate of 20 South African Mutton Merino ewes with lambs/ha was applied. The treatments were: Control: continuous grazing - no creep feed; forward creep grazing by the lambs in a rotational grazing system in which lambs were allowed to graze paddocks allocated to the ewes plus the next paddock in their series of grazing paddocks; $100 \mathrm{~g}$ creep feed/lamb/day; $250 \mathrm{~g}$ creep feed/lamb/day and creep feed ad libitum. The grazing system applied for all pre- and post-weaning treatments, except the continuous grazing treatment, was an eight-camp rotational system with a fixed period of stay of 3.5 days per camp. This allowed for a 24.5-day re-growth period. The rotational grazing area was divided into eight blocks. Each block was divided into three camps and randomly allocated to each of the three creep feed treatments. The ewes with lambs were allocated to the treatments using a randomised block design, blocking for body weight, birth status (singles and twins), age and sex. The lambs were weaned at an average of 100 days of age. Creep feed (without a cocciodiostat) was made available on a daily basis from approximately two weeks post partum. Faecal worm egg and oocyst counts were conducted on a weekly basis by Allerton Veterinary Laboratories. Strategic internal parasite control was based on the faecal egg counts.

The sheep had free access to fresh water in portable water troughs connected to a permanent water supply, and a mineral lick consisting of $34 \%$ salt, $33 \%$ bone meal and 33\% feed lime. The same concentrate mixture was used as both the creep feed and the supplement for the weaned lambs, and consisted of $68 \%$ maize meal, $15 \%$ lucerne meal, $10 \%$ molasses powder, $5 \%$ of a commercial high protein concentrate (HPC; $380 \mathrm{~g} \mathrm{CP} / \mathrm{kg}$; urea free), $1 \%$ feed lime and $1 \%$ salt and had an estimated composition (DM basis) of $12.3 \mathrm{MJ}$ $\mathrm{ME} / \mathrm{kg}, 117 \mathrm{~g} \mathrm{CP} / \mathrm{kg}, 63 \mathrm{~g}$ crude fibre $/ \mathrm{kg}, 9.7 \mathrm{~g}$ calcium $(\mathrm{Ca}) / \mathrm{kg}$ and $3.4 \mathrm{~g}$ phosphorus $(\mathrm{P}) / \mathrm{kg}$. The concentrate intake per group was recorded daily. During both the pre- and post-weaning trials a trough space of approximately $20 \mathrm{~cm}$ was allowed per lamb to minimize competition for concentrates.

During both trials, pasture availability was measured with a pasture disc meter (Bransby \& Tainton, 1977) and expressed in $\mathrm{cm}$ of disc meter height (disc height). The mean disc height before (initial) and after (residual) grazing was calculated from 25 readings per paddock.

The ram lambs remained on the ryegrass during the post-weaning phase of the trial. The stocking rate was $50 \mathrm{lambs} / \mathrm{ha}$. A rotational grazing system, as applied in the pre-weaning phase, was applied for all treatments. The lambs were re-allocated to treatments according to weaning weight, in such a way that the lambs in each of the pre-weaning treatments were represented in each post-weaning treatment. The treatments were: Control - no supplement; $250 \mathrm{~g}$ of supplement/lamb/day (only the second season); $500 \mathrm{~g}$ of supplement/lamb/day; ad lib. supplement. The lambs had free access to fresh water in portable water troughs connected to a permanent water supply, and a mineral lick consisting of $34 \%$ salt, $33 \%$ feed lime and $33 \%$ of a commercial phosphate supplement containing $12 \% \mathrm{P}$. Upon reaching an average live weight of 35 $\mathrm{kg}$ per treatment, the carcase grades of the lambs were estimated every 14 days on the hoof. Once $80 \%$ of the lambs in a treatment classified A3, the lambs in that treatment were slaughtered at the Cato Ridge abattoir (In the South African meat classification system the A in the A3 grade represents lambs with no permanent incisors and the 3, a carcass with more than $8.6 \%$ but less than $11.6 \%$ subcutaneous fat, 
SAMMIC, 2002). When the ryegrass became in short supply at the end of a season the lambs in treatments that did not achieve the $80 \%$ A3 grading were sent to the abattoir. All lambs were shorn prior to despatch to the abattoir. Wool samples from the midrib area were taken from each fleece and analysed at the SA Fleece Testing Centre at Grootfontein for fibre diameter and clean yield.

Analysis of variance, using Statgraphics (1988), on the animal performance data was carried out to test the significance of differences between treatments. An exponential function was fitted to ADG (Y) and supplement intake (X) by using Genstat Fitcurve Direction (1993).

\section{Results and Discussion}

During both seasons, the pre-weaning ADG's of lambs over the grazing periods of 84 days as well as their weaning weights did not differ among treatments (Table 1). The ADG's of the lambs for the period 14 to 42 days did not vary significantly among treatments. This suggests that the ingestion of milk during the first 42 days of lactation was sufficient to supply in the nutrient needs of the lambs, including the control, (de Villiers et al., 1993).

Table 1 Number of ewes and lambs used, supplement consumed by lambs, average daily gain (ADG), weaning weight of lambs and pasture height of Italian ryegrass during two seasons

\section{Treatments}

Control (no creep feed) Forward creep $\quad$ Amount supplemented (g/day)

\begin{tabular}{|c|c|c|c|c|c|}
\hline & & & 100 & 250 & Ad lib. \\
\hline \multicolumn{6}{|l|}{ Season 1: } \\
\hline Number of ewes & 12 & 12 & 12 & 12 & 12 \\
\hline Number of lambs & 12 & 15 & 15 & 15 & 15 \\
\hline \multicolumn{6}{|l|}{$\begin{array}{l}\text { Supplement consumed* } \\
\text { (g/lamb/day) }\end{array}$} \\
\hline 14 to 42 days & - & - & 60 & 108 & 120 \\
\hline 42 days to weaning & - & - & 100 & 231 & 517 \\
\hline \multicolumn{6}{|l|}{ ADG (g/day) } \\
\hline 14 to 42 days & $262 \pm 14$ & $249 \pm 8$ & $243 \pm 24$ & $233 \pm 15$ & $258 \pm 13$ \\
\hline 42 days to weaning & $196^{\mathrm{a}} \pm 9$ & $221^{\mathrm{a}, \mathrm{b}} \pm 12$ & $206^{\mathrm{a}, \mathrm{b}} \pm 13$ & $240^{\mathrm{b}} \pm 14$ & $297^{\mathrm{c}} \pm 14$ \\
\hline Over 84 days & $240 \pm 10$ & $240 \pm 8$ & $231 \pm 19$ & $235 \pm 13$ & $271 \pm 11$ \\
\hline Weaning weight (kg) & $23.4 \pm 1.47$ & $23.0 \pm 0.81$ & $22.5 \pm 1.69$ & $22.8 \pm 1.08$ & $25.0 \pm 1.04$ \\
\hline Ewe weight change (kg) & $-4.7 \pm 0.85$ & $-8.2 \pm 0.54$ & $-6.8 \pm 1.40$ & $-5.3 \pm 1.03$ & $-7.7 \pm 1.91$ \\
\hline Initial pasture height $(\mathrm{cm})$ & 3.2 & 4.7 & 5.1 & 5.4 & 5.1 \\
\hline \multicolumn{6}{|l|}{ Season 2: } \\
\hline Number of ewes & 12 & 11 & 9 & 11 & 12 \\
\hline Number of lambs & 13 & 14 & 10 & 12 & 14 \\
\hline \multicolumn{6}{|l|}{$\begin{array}{l}\text { Supplement consumed* } \\
\text { (g/lamb/day) }\end{array}$} \\
\hline 14 to 42 days & - & - & 77 & 134 & 140 \\
\hline 42 days to weaning & - & - & 100 & 250 & 489 \\
\hline \multicolumn{6}{|l|}{$\mathrm{ADG}(\mathrm{g} /$ day $)$} \\
\hline 14 to 42 days & $226 \pm 19$ & $239 \pm 16$ & $222 \pm 26$ & $190 \pm 12$ & $207 \pm 17$ \\
\hline 42 days to weaning & $198 \pm 10$ & $243 \pm 12$ & $228 \pm 32$ & $243 \pm 15$ & $257 \pm 20$ \\
\hline Over 84 days & $211 \pm 12$ & $238 \pm 11$ & $222 \pm 26$ & $213 \pm 9$ & $228 \pm 16$ \\
\hline Weaning weight (kg) & $23.1 \pm 1.38$ & $25.2 \pm 1.18$ & $25.4 \pm 2.61$ & $23.7 \pm 0.78$ & $25.2 \pm 1.65$ \\
\hline Ewe weight change (kg) & $4.5 \pm 1.24$ & $8.5 \pm 1.85$ & $4.8 \pm 2.45$ & $7.0 \pm 1.12$ & $5.1 \pm 1.65$ \\
\hline Initial pasture height $(\mathrm{cm})$ & 6.3 & 12.3 & 14.1 & 13.5 & 14.1 \\
\hline
\end{tabular}

${ }^{a-c}$ Values in the same row with different superscripts are significantly $(\mathrm{P}<0.001)$ different.

* "as is" basis.

The ADG of lambs during Season 1 improved $(\mathrm{P}<0.001)$ with increasing levels of supplement for the 
period from 42 days of age to weaning. A similar trend $(\mathrm{P}=0.190)$ was recorded during Season 2 . The lambs in the unsupplemented treatments showed continued good growth after peak lactation of their dams. This did not agree with the poor growth of lambs on ryegrass during the last weeks before weaning, as observed by De Villiers et al. (1993). Not withstanding the good growth rates of the supplemented lambs from 42 days to weaning compared to the unsupplemented treatments, weaning weights among treatments did not differ significantly (Table 1). Lamb growth from 42 days to weaning (Table 1) in the forward creep grazing system did not differ from that of the lambs in the Control. When comparing creep grazing with set stocking densities, Conway (1968) recorded significantly better growth in lambs on the creep grazing only in one of five years. It could be speculated that a forward creeping system should be more advantageous at higher stocking rates than the present, since the lambs then would have unrestricted access to high quality grazing. However, such a system would be at the cost of ewe performance. The difference in average pre-grazing pasture heights over the two seasons (Table 1) indicates a difference in pasture availability between the two seasons. The lower pasture availability during Season 1 is reflected in the 7 to $12.5 \%$ weight loss of the ewes over the trial period, while during Season 2 they gained 9 to $17 \%$. Despite the weight loss of the ewes during Season 1, their lambs maintained growth rates similar to those of the lambs receiving the supplements. This confirmed the ability of ewes to sacrifice their own body tissues when under nutritional stress in favour of milk synthesis to sustain the growth of their lambs (Williams et al., 1976). Creep feeding of their lambs did not affect the weight changes of their dams (Table 1).

Creep feed intake was $c .15 \mathrm{~g} / \mathrm{lamb} /$ day when offered to the lambs at an age of two weeks. That increased to $c .630 \mathrm{~g} / \mathrm{lamb} /$ day during the last week before weaning (Table 2). The average concentrate intakes in the $a d l i b$. creep feed treatments over the 84 days were 340 and $334 \mathrm{~g} / \mathrm{lamb} /$ day during the two seasons respectively (Table 1). Creep feed intake increased consistently with time to $c$. 25 to $30 \mathrm{~g} / \mathrm{kg}$ body weight (Table 2), after which it stayed relatively constant.

Table 2 Mean creep feed intake ("as is" basis) per day and concentrate intake relative to body weight of the pre-weaned lambs in the treatments where the supplement was offered ad libitum

\begin{tabular}{|c|c|c|c|c|c|c|}
\hline \multirow{2}{*}{$\begin{array}{c}\text { Week of } \\
\text { supplementation }\end{array}$} & \multicolumn{3}{|c|}{ Season 1} & \multicolumn{3}{|c|}{ Season 2} \\
\hline & $\begin{array}{l}\text { Creep feed } \\
\text { intake } \\
\text { (g/lamb/day) }\end{array}$ & $\begin{array}{l}\text { Lamb } \\
\text { weight } \\
(\mathrm{kg})\end{array}$ & $\begin{array}{c}\text { Creep intake/ } \\
\text { kg body } \\
\text { weight } \\
\text { (g) }\end{array}$ & $\begin{array}{l}\text { Creep feed } \\
\text { intake } \\
\text { (g/lamb/day) }\end{array}$ & $\begin{array}{l}\text { Lamb } \\
\text { weight } \\
(\mathrm{kg})\end{array}$ & $\begin{array}{c}\text { Creep intake } \\
\text { kg body } \\
\text { weight }(\mathrm{g})\end{array}$ \\
\hline 3 & 55 & 10.2 & 5.4 & 19 & 8.4 & 2.2 \\
\hline 4 & 75 & 11.4 & 6.6 & 100 & 12.9 & 7.8 \\
\hline 5 & 158 & 13.2 & 11.9 & 188 & 13.8 & 13.7 \\
\hline 6 & 193 & 15.7 & 12.3 & 255 & 15.4 & 16.5 \\
\hline 7 & 275 & 16.5 & 16.7 & 286 & 17.2 & 16.6 \\
\hline 8 & 374 & 18.5 & 20.2 & 431 & 18.9 & 22.8 \\
\hline 9 & 657 & 21.5 & 30.5 & 535 & 20.9 & 25.6 \\
\hline 10 & 622 & 24.4 & 25.5 & 602 & 22.6 & 26.6 \\
\hline 11 & 658 & 25.0 & 26.3 & 591 & 24.0 & 24.6 \\
\hline
\end{tabular}

Supplementation during both seasons improved $(\mathrm{P}<0.001)$ the ADG's of the weaned lambs above those of the control groups (Table 3). The lambs in both the $500 \mathrm{~g} / \mathrm{lamb} /$ day and ad lib. treatments were marketed during Seasons 1 and 2 respectively 35 and 28 days earlier than the unsupplemented lambs. Due to the relatively slow growth of the lambs in the control during Season 2 their carcass weights were lower $(\mathrm{P}<$ 0.001) than those of the supplemented lambs. Pre-weaning treatment was found to have no effect on postweaning gain, contrary to the findings of de Villiers et al. (1995). There were no significant differences in carcass weight among the treatments for Season 1. The variation in lamb performance and post-weaning growth between years is clearly illustrated by the difference in ADG's of 132 and $42 \mathrm{~g}$ /day of the weaned lambs in the control treatments in Seasons 1 and 2 respectively. In contrast to ewes' pre-weaning performance it should be noted that the pasture was shorter in Season 1 than in Season 2 (Table 3).

The data illustrated in Figure 1 suggested that no significant response was achieved by supplementing a lambs at level of higher than $500 \mathrm{~g}$ /day. The non-linear relations for supplement intake (X) and $\mathrm{ADG}(\mathrm{Y})$ for the two seasons were:

Season 1: $\mathrm{Y}=203.4-63.54 \mathrm{e}-0.00292 \times \mathrm{X}$

Season 2: $\mathrm{Y}=239.3-198.4 \mathrm{e}-0.00292 \mathrm{xX}$

$$
\left(\mathrm{S}_{\mathrm{y} . \mathrm{x}}=32.9 ; \mathrm{R}^{2}=72.5 ; \mathrm{n}=63 ; \mathrm{P}<0.01 ; \text { both seasons }\right)
$$


Both seasons: $\mathrm{Y}=214.1-112.9 \mathrm{e}-0.00278 \mathrm{xX}\left(\mathrm{S}_{\mathrm{y} . \mathrm{x}}=43.9 ; \mathrm{R}^{2}=51.1 ; \mathrm{n}=63 ; \mathrm{P}<0.01\right)$

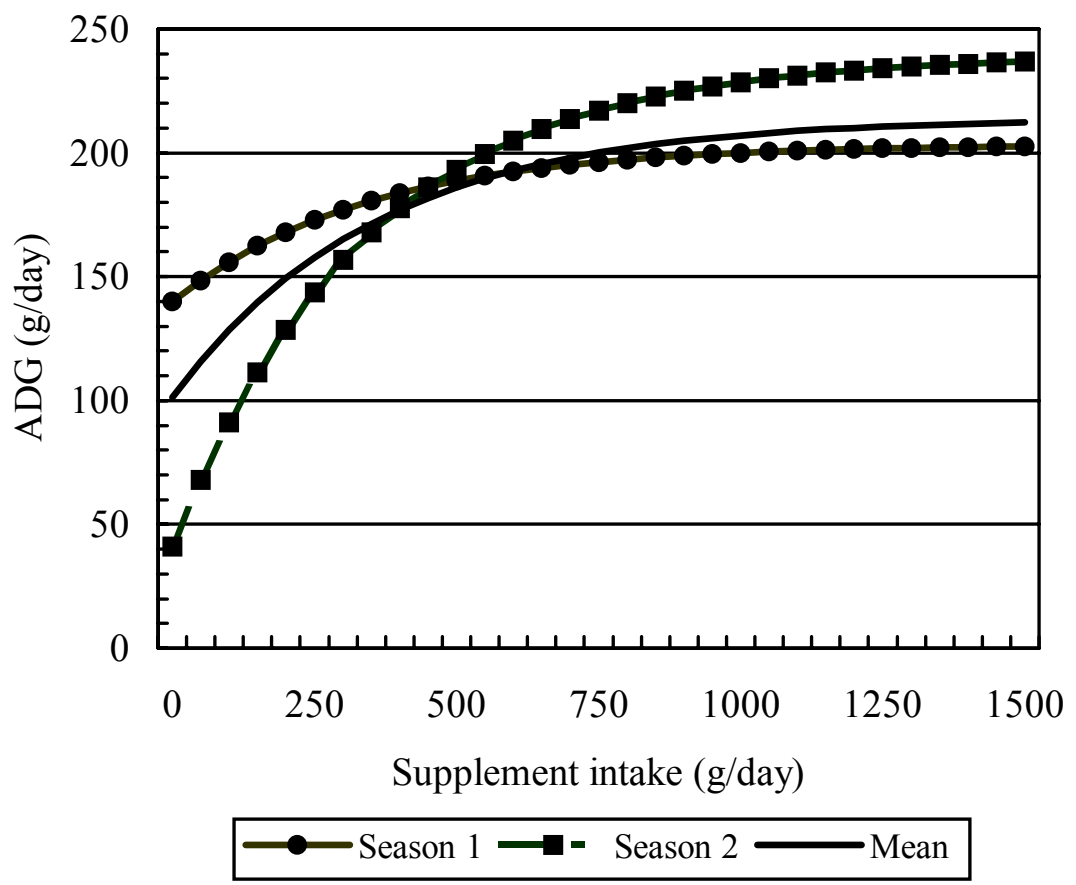

Figure 1 The relationship between supplement intake and average daily gain (ADG) of weaned lambs on ryegrass during Season 1, Season 2 and the mean of the two seasons

The curvilinear nature of the growth response curve to supplementary concentrate feeding determined in this trial is similar to the diminishing returns responses, determined for milk production in dairy cows on pastures fed different levels of concentrate (Dugmore et al., 1997). The relationship between energy intake and milk yield in dairy cows is curvilinear (Blaxter, 1962; Dean et al., 1972; Gordon, 1984) with the marginal milk response decreasing as the level of concentrate increases. These curvilinear responses could be attributed to changes in the substitution rate of roughages by concentrates. Faverdin et al. (1991) showed that the substitution of roughages by concentrates increases with increasing levels of concentrate feeding. Consequently, the additional gain in energy per increment of concentrate fed, decreased as the substitution rate increased, resulting in the curvilinear relationships measured. Analyses of pasture consumption, as measured by disc meter (Table 3) was $10 \%$ and $27 \%$ lower (per kg body weight) for the $a d$ lib. treatment relative to the control, for Season 1 and 2 respectively. This suggests that substitution of roughage by concentrates occurred. The depression in intake was linearly related to the amount of supplement fed. Holmes (1975) showed that the substitution rate of roughages by concentrates increased as the digestibility of the roughage increased. This substitution effect increased from $35 \%$ in forage with a digestibility of $40 \%$ to a value exceeding $80 \%$ in highly digestible forages (c. $80 \%$ digestible DM). This increasing rate of substitution with increasing digestibility of forages resulted in diminishing animal production responses to concentrate as forage quality increases. These diminishing responses have been found in practice with dairy cows at Cedara. In dairy cows on kikuyu the milk production response per $\mathrm{kg}$ concentrate supplementation (c. 9.0 MJ ME/kg DM; Dugmore, 1998a) was $1.2 \mathrm{~kg}$ fat corrected milk (FCM) (Dugmore, 1998b) and on fescue, $0.88 \mathrm{~kg} \mathrm{FCM} / \mathrm{kg}$ concentrate (c. $9.4 \mathrm{MJ} \mathrm{ME} / \mathrm{kg} \mathrm{DM}$; Dugmore et al., 1992). Stockdale (1998) measured similar milk production responses to concentrate supplementation on herbages of differing energy concentrations. Marginal responses diminished linearly from $1.25 \mathrm{~kg} \mathrm{FCM} / \mathrm{kg}$ $\mathrm{DM}$ at a herbage ME of $8 \mathrm{MJ} / \mathrm{kg} \mathrm{DM}$ to $0.3 \mathrm{~kg} \mathrm{FCM} / \mathrm{kg}$ concentrate DM at a ME of $12 \mathrm{MJ} / \mathrm{kg}$ herbage DM. These factors may explain some of the variation in the growth responses of the lambs to supplements during and between seasons. Similarly, in sheep Milne et al. (1981) recorded substitution rates of $61 \%$ on an organic matter basis on sward heights held at $2 \mathrm{~cm}$ and $87 \%$ on a less severely grazed sward maintained at 3 $\mathrm{cm}$. Milne et al. (1981) also found that increasing rate of supplement depressed the organic matter digestibility of the herbage by 0.50 percentage units per $100 \mathrm{~g}$ supplemental organic matter when individually penned ewes were given four amounts of supplement and offered $a d$ lib. freshly-cut perennial 
ryegrass herbage.

The economic response of supplementation will vary significantly from season-to-season depending on the reigning production costs of pasture, the cost of concentrates and market price of the lambs, all of which differ from season-to-season and farm-to-farm. In the present study concentrate intake levels exceeding $500 \mathrm{~g} /$ day were not profitable.

Clean wool yield among the treatments was not significantly different. During Season 2 supplementation increased $(\mathrm{P}<0.014)$ the fibre diameter. The lambs gained on average $132 \mathrm{~g} /$ day during Season 1. It was, therefore, possible during some seasons to produce a slaughter lamb with a carcass weight of $19.8 \mathrm{~kg}$ and a carcass fat coverage of $1.8 \mathrm{~mm}$ on annual ryegrass without supplementation. However, it took approximately four months to produce a slaughter lamb without supplementation compared to three months and less for lambs supplemented at $500 \mathrm{~g}$ /day and $a d l i b$.

Table 3 Supplement intake, average daily gain (ADG), pasture height, days to marketing and carcass weight of lambs post-weaning on Italian ryegrass with and without supplement

\begin{tabular}{|c|c|c|c|c|}
\hline \multirow[t]{3}{*}{ Parameter } & \multicolumn{4}{|c|}{ Treatments } \\
\hline & \multirow{2}{*}{$\begin{array}{l}\text { Control } \\
\text { (no supplement) }\end{array}$} & \multicolumn{3}{|c|}{ Amount supplemented (g/day) } \\
\hline & & 250 & 500 & Ad lib. \\
\hline \multicolumn{5}{|l|}{ Season 1: } \\
\hline Number of lambs & 13 & & 14 & 13 \\
\hline $\begin{array}{l}\text { Supplement intake* from weaning to } \\
\text { marketing (g/lamb/day) }\end{array}$ & - & - & 500 & 1519 \\
\hline Initial body weight $(\mathrm{kg})$ & $26.1 \pm 1.32$ & - & $27.8 \pm 1.14$ & $28.6 \pm 1.50$ \\
\hline Final body weight $(\mathrm{kg})$ & $36.7 \pm 1.35$ & - & $41.6 \pm 1.57$ & $43.7 \pm 1.29$ \\
\hline $\mathrm{ADG}$ (g/day) over 77 days & $132^{\mathrm{a}} \pm 11.20$ & - & $169^{\mathrm{b}} \pm 10.11$ & $190^{\mathrm{b}} \pm 4.53$ \\
\hline Pasture height $(\mathrm{cm})$ & & - & & \\
\hline Initial & 6.2 & - & 7.1 & 8.6 \\
\hline Residual & 1.9 & - & 2.4 & 4.0 \\
\hline Difference (Pasture consumption) & 4.3 & & 4.7 & 4.6 \\
\hline Days to marketing & 119 & & 84 & 77 \\
\hline Carcass weight (kg) & $19.8 \pm 0.809$ & & $21.5 \pm 0.739$ & $21.8 \pm 0.975$ \\
\hline \multicolumn{5}{|l|}{ Season 2: } \\
\hline Number of lambs & 8 & 6 & 5 & 5 \\
\hline $\begin{array}{l}\text { Supplement intake* from weaning to } \\
\text { marketing (g/lamb/day) }\end{array}$ & - & 250 & 500 & 1011 \\
\hline Initial body weight (kg) & $26.4 \pm 1.12$ & $26.6 \pm 1.69$ & $24.5 \pm 1.08$ & $23.1 \pm 0.56$ \\
\hline Final body weight (kg) & $30.1 \pm 1.03$ & $39.2 \pm 2.07$ & $42.5 \pm 1.83$ & $44.3 \pm 0.82$ \\
\hline ADG (g/day) over 91 days & $42^{\mathrm{a}} \pm 15.22$ & $146^{\mathrm{b}} \pm 11.84$ & $209^{c} \pm 15.73$ & $247^{\mathrm{c}} \pm 5.44$ \\
\hline \multicolumn{5}{|l|}{ Pasture height $(\mathrm{cm})$} \\
\hline Initial & 15.6 & 15.1 & 16.1 & 17.8 \\
\hline Residual & 5.2 & 4.9 & 5.7 & 6.6 \\
\hline Difference (Pasture consumption) & 10.4 & 10.2 & 10.4 & 11.2 \\
\hline Days to marketing & 119 & 105 & 91 & 91 \\
\hline Carcass weight (kg) & $11.8^{\mathrm{a}} \pm 0.45$ & $18^{\mathrm{b}} \pm 1.26$ & $19.2^{\mathrm{b}} \pm 0.86$ & $20.0^{\mathrm{b}} \pm 0.63$ \\
\hline
\end{tabular}

${ }^{\mathrm{a}-\mathrm{c}}$ Values in the same row with different superscripts are significantly $(\mathrm{P}<0.001)$ different.

* "as is" basis.

\section{Conclusion}

In the present study, creep feeding had no significant effect on the weaning weights of lambs or on the 
performance of the ewes. However, post-weaning supplementation on ryegrass shortened the period from weaning to marketing by approximately one month, thereby reducing the risks of losses through theft, mortalities and health problems such as parasites and footrot. Creep feed intake measured in this study increased from $c .15 \mathrm{~g} / \mathrm{lamb} /$ day at introduction at 2 weeks of age to $c .630 \mathrm{~g} / \mathrm{lamb} / \mathrm{day}$, with an average of between 300 and $350 \mathrm{~g} / \mathrm{lamb} /$ day over a period of 84 days to weaning. No significant advantage in weight gain was achieved by supplementing the weaned lambs on Italian ryegrass pastures at levels of higher than $500 \mathrm{~g} /$ day. However, supplementation offers a useful strategy to improve production when used strategically during periods of feed shortage.

\section{Acknowledgements}

C. Stevens is thanked for assistance with the statistical analyses.

\section{References}

Blaxter, K.L., 1962. The energy metabolism of ruminants. Hutchinson \& Co. Publ. Ltd. London W.1.

Bransby, D.I. \& Tainton, N.M., 1977. The disc pasture meter: possible applications in grazing management. Proc. Grassld. Soc. Sthn. Afr. 12, 115-118.

Comway, A., 1968. Some problems associated with grassland farming. Wld. Rev. Anim. Prod. 18, 62-68.

Dean, G.W., Carter, H.O., Wagstaff, H.R., Olayide, S.O., Ronning, M. \& Bath, D.L., 1972. Production functions and linear programming models for dairy cattle feeding. Giannini Foundation Monograph 31.

De Villiers, J.F. \& Botha, W.A. \& Smith, M.F., 1993. The effect of stocking rate on the performance of ewes and lambs of Italian ryegrass. S. Afr. J. Anim. Sci. 23, 43-50.

De Villiers, J. F., Dugmore, T.J. \& Botha, W.A., 1995. The relationship between pre- and post-weaning performance of lambs on Italian ryegrass. S. Afr. J. Anim. Sci. 25, 16-20.

Dugmore, T.J., 1995. The chemical composition and nutritive value of selected KwaZulu-Natal feedstuffs. In Dairying in KwaZulu-Natal. Ed. Dugmore, T.J., KwaZulu-Natal Department of Agriculture. pp. 211 $-226$.

Dugmore, T.J., 1998a. Energy and mineral content of kikuyu. In: Proceedings of kikuyu technology day. Ed. Bartholomew, P.E., KwaZulu-Natal Department of Agriculture. pp. 12-14.

Dugmore, T.J., 1998b. Dairy production from kikuyu. In: Proceedings of kikuyu technology day. Ed. Bartholomew, P.E., KwaZulu-Natal Department of Agriculture. pp. 34-35.

Dugmore, T.J., van der Merwe, B.J., Meaker, M.J. \& Walsh, K.P., 1997. Concentrate feeding responses of dairy cows grazing pasture. Paper presented at Congress 32, Grassld. Soc. Sthn. Afr., Port Elizabeth, January 1997.

Dugmore, T.J., Walsh, K.P., Morning, S.J. \& Macdonald, C.J., 1992. Chemical composition and nutritive value of irrigated tall fescue for dairy cows. S. Afr. J. Anim. Sci. 22, 81-86.

Faverdin, P., Dulphy, J.P., Coulon, J.B., Verite, R., Garel, J.P., Rouel, J, \& Marquis, B., 1991. Substitution of roughage by concentrates for dairy cows. Livest. Prod. Sci. 27, 137-156.

Genstat, 1993. Genstat 5 Committee of the Statistics Department, Rothamsted Experimental Station. Genstat 5, Release 3 Reference Manual. Oxford, Clarendon Press.

Gibb, M.J. \& Treacher, T.T., 1978. The effect of herbage allowance on herbage intake and performance of ewes and their twin lambs grazing perennial ryegrass. J. Agric. Sci., Camb. 90, 139-147.

Gordon, F.J., 1984. The effect of level of concentrate supplementation given with grass silage during the winter on total lactation performance of autumn-calving dairy cows. J. Agric. Sci. Camb. 102, 163179.

Holmes, W., 1975. Aspects of the use of energy and concentrate feeds in grazing management. In: Occ. Publ. No 8 Br. Grassld. Soc. Eds. Hodgson, J. \& Jackson, D.K. pp.141-145.

Jagusch, K.J., Rattray, P.V., Oliver, T.W. \& Cox, N.R., 1979. The effect of herbage yield and allowance of growth and carcass characteristics of weaned lambs. Proc. N.Z. Soc. Anim. Prod. 39, 254-259.

Joyce, J.P. \& Rattray, P.V., 1970. The intake and utilization of milk and grass by lambs. Proc. N.Z. Soc. Anim. Prod. 30, 94-105.

Johnson, C.L. \& Light, M.R., 1965. Creep feeding lambs before pasture grazing. N. Dakota Farm Res. 23, 18 -19. (Cited by Terblanche et al., 1973).

Langlands, J.P. \& Donald, G.E., 1975. The intakes and growth rates of grazing Border Leicester x Merino lambs weaned at 21, 49 and 77 days. Anim. Prod. 21, 175-181.

Light, M.R. \& Haugse, L.N., 1965. Creep feeding lambs on pasture. N. Dakota Farm Res. 23, 11-13. (Cited by Terblanche et al., 1973).

Milne, J.A., Maxwell, T.J. \& Souter, W., 1981. Effect of supplementary feeding and herbage mass on the 
intake and performance of grazing ewes in early lactation. Anim. Prod. 32, 185-195.

Robinson, J.J., 1990. Technology advances and the sheep of the future. Proc. 42nd Ruakura Farmers' Conf. June 1990. pp.158-162.

SAMMIC, 2002. Agricultural Product Standards Act, 1990 (Act No. 119 of 1990). Regulations regarding the classification and marketing of meat. http://www.samic.co.za/FS/Regulasies.htm

Smith, H.R.H., Bransby, D.I. \& Tainton, N.M., 1986. The characterization of irrigated Midmar Italian ryegrass in the South Eastern Transvaal Highveld using slaughter lambs. J. Grassl. Soc. Sthn Afr. 3, $14-18$

Statgraphics, 1988. Statistical Graphic System. Statistical Graphics Corporation Inc., Rockville, Maryland.

Stockdale, C.R., 1998. Influences of the metabolisable content of herbage on milk yield responses to concentrate supplements in grazing dairy cows. Animal Production in Australia. 22, 375.

Terblanche, I.L., Mulder, A.M., Nel, L.P. \& Rossouw, J.W., 1973. Uitwerking van kruipvoeding en byvoeding op massatoename en karkasgradering van Dorper-lammers. Agroanimalia. 5, 1-6.

Thomson, D.J., 1982. The nitrogen supplied by and the supplementation of fresh or grazed forage. Forage protein in ruminant animal production. Occ. Publ. No. 6. Br. Soc. Anim. Prod.

Van Ryssen, J.B.J., Short, A.M. \& Lishman, A.W., 1976. Carbohydrate supplementation of lambs on kikuyu pasture. Agroanimalia. 8, 43-48.

Warner, J.R. \& Sharrow, S.H., 1984. Set stocking, rotational grazing and forward rotational grazing by sheep on western Oregon hill pastures. Grass Forage Sci. 39, 331-338.

Williams, C.M.J., Geytenbeek, P.E. \& Allden, W.G., 1976. Relationship between pasture availability, milk supply, lamb intake and growth. Proc. Aust. Soc. Anim. Prod. 11, 333-336. 